\title{
A DATABase For COMPARing THe OPERATIONAL CONCEPTS OF HIGH-SPEED RAILWAYS IN EUROPE
}

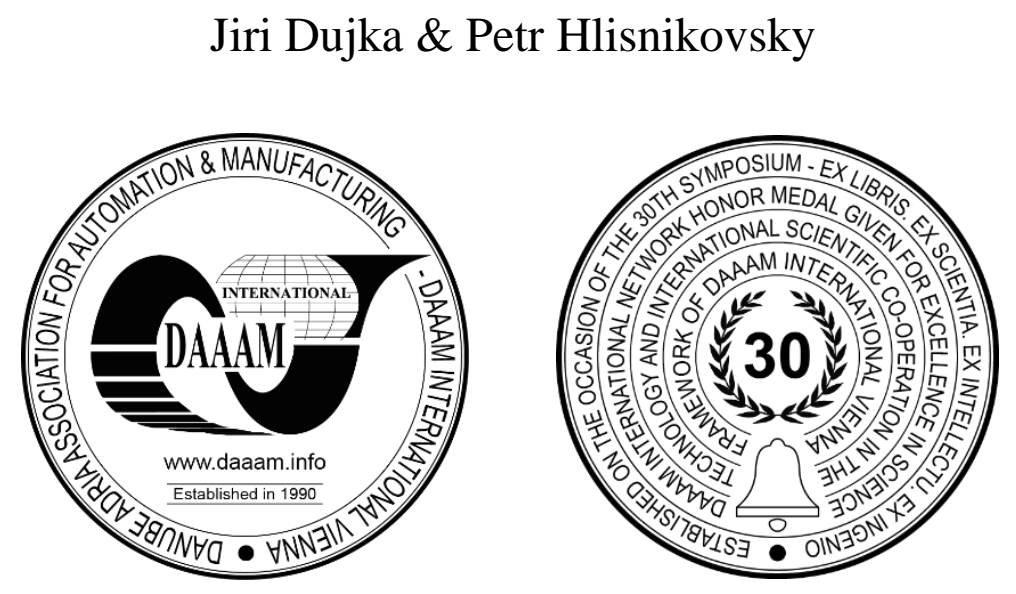

This Publication has to be referred as: Dujka, J[iri] \& Hlisnikovsky, P[etr] (2019). A Database for Comparing the Operational Concepts of High-speed Railways in Europe, Proceedings of the 30th DAAAM International Symposium, pp.0770-0774, B. Katalinic (Ed.), Published by DAAAM International, ISBN 978-3-902734-22-8, ISSN 1726-9679, Vienna, Austria

DOI: $10.2507 / 30$ th.daaam.proceedings.106

\begin{abstract}
Operational concepts of high-speed rails in Europe differ in each country or network. The differences are mainly in train categories, frequency of connections or in the degree of combination of high speed and conventional rail operation. To quantify the characteristics of each conception, a European-wide, multi-national database similar to online connection browsers has been designed. This database is based on timetable data and create a foundation for further analyses. The database is designed in SQL domain-specific language, using pgAdmin. The described draft of the database is still under testing and re-creating to perfect the content and usage. This paper sums up the formation of the database and describes each part of the database.
\end{abstract}

Keywords: database; SQL; pgAdmin; timetables; high-speed rails; railways; Europe

\section{Introduction}

High-speed rail systems exist in many European countries. Networks of high-speed rails are established primarily at the national level. In international comparison, there can be found structural and operational differences ([1], [2]). Both the TEN-R conception [3] and the more general EU regulation ([4], [5]) provide a general framework for high-speed rails in Europe. The disposition of the networks in each European country can be compared, for example, in terms of network development [6], transport performance [7], attitude to operation of rail transport ([8], [9]), relation to air transport, to which the high-speed rail network is often compared ([10], [11], [12]) or in terms of terminal creation policy [13].

However, there is little regard for the disposition of the operating models in each country, which means, for example, the disposition of the network in terms of line arrangement, frequency of connections, a number of train levels, terminal policy, travel time. The aim of presented research is to examine these characteristics in more detail, whereas the basis is to determine the exact characteristics of the operating models in each country. To find these characteristics, a database containing traffic data based on direct timetable analysis is created. This method has already been used in geography ([14], [15]) and belongs to the group of quantitative data analysis together with, for example, the analysis of big data ([16], [17]), or information about work and study commuting ([15], [18]). 
In this paper, the creation of the database is described. The evolution of the database concerning the needs of the researched topic is presented in chapter 2 . The database architecture is described in chapter 3 . Overall results and the main goals of further research are provided in chapter 4.

\section{Database development and data range selection}

A standard method used to compare the characteristics of rail transport, or high-speed rail transport, is the method of direct timetable analysis. The advantage of this method is an easy orientation in the timetables and the resulting possibility of a quick acquisition of aggregated data. The disadvantage of this method is the creation of a unique solution corresponding only to the assignment. The resulting aggregated data cannot be used for other analyses, and no other characteristics can be determined from them. The possibility of processing primary, non-aggregated timetable data is the main benefit of the database approach, which is, therefore, used in this research. The database of operational characteristics of high-speed rail transport is filled with primary data and characteristics of train lines and trains (train number, arrival and departure for appropriate station, operational restrictions, etc.). Then, it is possible to find out the necessary data not only for individual stations or trains but also for the whole state or its part. The disadvantages of database approach are, in particular, the need to process a large amount of data to fill the database and the computational complexity of an extensive database.

The primary intention was to fill the database with all trains related to the operation on high-speed lines in Europe. However, this represented an extraordinary amount of data. When defining the number of links in this way, the degree of interconnection of traffic on the high-speed and conventional networks depends very much. For example, the operational concept of the rail network in Germany or Austria uses high-speed lines as a complement to conventional rail traffic. High-speed railways in these countries are of similar importance to motorways in the road network. This implies that trains which are not operated in a high-speed mode often use the high-speed network (for example, some regional passenger trains serving more distant parts of suburban region). The opposite situation is, for example, in Spain. There is almost no interconnection of traffic on the conventional and high-speed rail network due to the different track gauge. High-speed rail is, by its nature, closer to air transport. Therefore, it is effortless to define only trains running on the highspeed rail network. Based on these findings, the scope of data which the database is filled with has been substantially reduced. Only top-quality trains which use the high-speed network are now considered. These trains are generally designed to connect the most important or largest urban agglomerations; therefore, they have only a few stations and a high average speed which is close to the designed speeds of high-speed lines.

Development of database architecture has gone through several developmental stages. The initial version was created and tested on a randomly selected part of the timetable of one of the spinal railways in the Czech Republic. This sample represented a combination of long-distance trains, regional long-distance passenger trains and commuter rail characterized by dense operation with short intervals. Based on the test results, the database was modified. In the second phase, the definition of the database content was refined, and the second version of the database was created. This database is currently filled with data and prepared for the next stage of testing. For the second version of the database, the timetables of trains running on high-speed lines in Italy and Spain were selected. If the testing is successful, in the third phase, the database will be filled with data for other European countries where high-speed railways are built.

\section{Database architecture}

The database is created in pgAdmin and programmed for the SQL query language. Applications for connection searching of public mass transport have become a model for the database (e.g. application of Deutsche Bahn [19], Czech application IDOS [20]). However, compared to the structure of these search engines, a few changes, which arise from the needs of future analyses, are required. These include:

- The possibility of quickly quantifying the number of trains or trains at each network point (railway station, regional terminal)

- The possibility to quickly quantify the travel time of the link and the average travel time between two selected points of the network

- The possibility to filter connections according to their operational restrictions (days of the week, seasonal operational restrictions, etc.)

- The possibility to filter connections according to a transport provider operating them

On the contrary, the following elements from the search engines were not considered:

- Connection price. At present, the so-called flexible tariff, where the price of the journey varies according to the time of the journey, but also according to the interest of the passengers based on booking systems, is often used. 
Working with such tariff characteristics would unnecessarily increase the amount of data in the database, regardless of the difficulty of obtaining it

- Train composition; this characteristic is not relevant for the foreseen analyses and would place too much burden on the database

- Link to calendar. For our analyses, data for graphicon 2018/2019 are processed, while timetables are generally approached (i.e. no specific week or month of the year). Instead, categories neglecting daily traffic restrictions are set, and a comprehensive solution is preferred. Therefore, it is not decisive whether the train runs on a particular calendar day, but whether it runs, for example, on a working day

The database consists of four tables (Fig. 1). The "train", "station" and "timetable" tables are tables with a 1:n relation and contain the data needed for analysis. The "main" table is a table with the m:n relation and serves only for interconnection of basic database components (i.e. it does not have own ID).

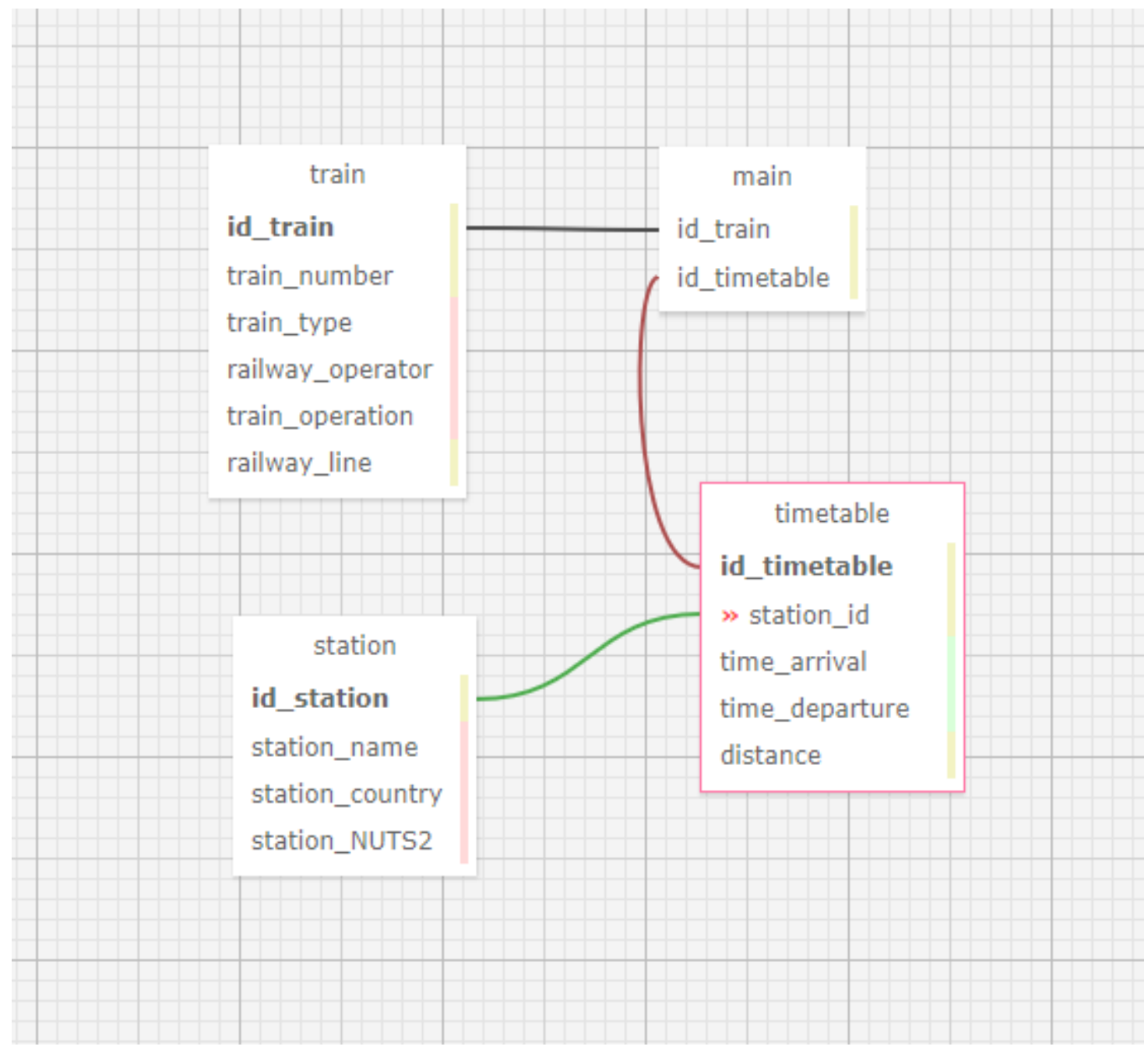

Fig. 1. Database schema. Created in the environment [21]. Colours for column name: yellow - integer, red - text, green datetime.

\section{1. "Train" table}

The "train" table contains train information. The column "ID_train" in the table represents the code consisting of the train number according to the timetable, the sequence number of the connection and the selected identifier of the country in which the train passes. This identifier is a three-digit code and is designed to eliminate the situation where two trains in two states may have the same number. The "train number" column is the train number from the timetable. The "train_type" column represents the train type specified in the timetable. The "railway_operator" column contains the name of the transport provider that operates the train. The "train_operation" column indicates operational restrictions. Operational restrictions are defined categories with partially aggregated data ("only on workday", "daily", "only on Saturday", etc.). The operational restriction consists of letter codes. The "railway_line" column represents the line on which the train runs according to the timetable. 
The connection sequence number is only entered if there are several variants of the train running. These are cases where a train marked with a single number runs a different part of the route with different restrictions. Then, two or more trains of the same timetable number, which are distinguished by a sequence number $(01,02$, etc.), are entered in the database.

\section{2. "Timetable” table}

The "timetable" table contains information about the train's position at each point (station, stop) on its route. Each train is considered to be a set of points oriented in time and space. Each train can be at one place only at one point in time. At the same time, each train has its tariff distance, which may differ from the tariff distances of lines or routes in the timetable. This concept of the train as a set of points was used because of the possibility of the train to run on multiple lines. Therefore, the linear concept, which represents one column in the timetable of the line concerned, has been abandoned. Therefore, one row in the "timetable" table contains the position of a particular train at a particular station with a specific arrival and departure time, whereas this point (station) is located at a certain distance from the starting station. The tariff mileage is used to calculate the average train speed.

The "ID_timetable" column contains the unique code of the point which the train passes. The "station_id" column contains a unique station code that is linked to a separate "station" table for additional information. The columns "time_arrival" and "time_departure" contain information about the arrival and departure of the train to the respective station. If there is an only one-time stamp in the timetable at the station concerned (usually it is the departure of the train from the station), the values in both columns are identical. If the train starts or ends at the station concerned, the appropriate arrival/departure column is null. The "distance" column shows the tariff mileage of the train from its starting station. The train starting station has a tariff mileage of zero.

\section{3. "Station" table}

The "station" table contains station information. The "ID_station" column contains the unique station code. The station codes are created for the database and consist of a country identifier (see description of the "train" table) and an assigned sequence number. Other information about the station is its name (column "station_name"), the country in which the station is located (column "station_country") and the station's affiliation to statistical territorial units (NUTS) (column "station_NUTS2"). Assignment of the station by NUTS 2 regions is used because of the possibility of subsequent spatial analysis for greater regional detail than the country (NUTS 1) or the entire state (NUTS0).

\section{4. "Main” table}

The "main" table is used only for linking two branches of the database. Including this table with the "m: n" relation makes it easier to query the database. Its task is purely operational and includes primary keys (IDs) from the "train" and "timetable" tables.

\section{Conclusion}

The database is created to analyse the operational characteristics of high-speed railways in European countries. The database will contain data from timetables. The database is similar in function to traffic search applications. Unlike these applications, some user-friendly content is suppressed, and the statistical component is preferred. The database is now in the testing phase and will be filled with the required data if successful.

Based on the results of working with the database in the indicated range, further possibilities of its use will be considered. The extension of the database to other levels of trains is possible, as well as the realization of the original intention to include all trains running on the high-speed infrastructure. However, finding out the characteristics of networks in individual European countries is only one of the outputs. Furthermore, the results should be compared with other geographical characteristics (settlement structure, demography, spatial structures of economic activities, etc.) and a comprehensive comparison of high-speed rail transport in European countries should be created. The outputs should be used to modify the design of the high-speed rail system in the Czech Republic.

\section{Acknowledgments}

This article is the output of the project called "New Mobility - High-Speed Transport Systems and Transport-Related Human Behaviour", Reg. No. CZ.02.1.01/0.0/0.0/16_026/0008430, co-financed by the "Operational Programme Research, Development and Education".

\section{References}


[1] Kušnír, J. \& Ilík, J. (2011). The philosophy of high-speed rails planning in the Czech Republic. Available from: http://www.silnice-zeleznice.cz/clanek/filozofie-planovani-vysokorychlostni-zeleznice-v-ceske-republice/ SILNICE ŽELEZNICE. Accessed on: 2019-10-01

Kušnír, J. \& Ilík, J. (2011). Filozofie plánování vysokorychlostní železnice v České republice.

[2] Dujka, J. \& Seidenglanz, D. (2019). (Dis)connection of high-speed rails between Western and Central Europe sheer coincidence, or inevitable consequence? Proceedings of $23^{\text {rd }}$ International Scientific Conference. Trasport Means 2019, in press.

[3] https://eur-lex.europa.eu/LexUriServ/LexUriServ.do?uri=CELEX:31996L0048:EN:HTML (1996). Council Directive 96/48/EC of 23 July 1996 on the interoperability of the trans-European high-speed rail system. Accessed on: 2019-09-28

[4] https://eur-lex.europa.eu/legal-content/EN/ALL/?uri=CELEX:32002D0735 (2002). 2002/735/EC: Commission Decision of 30 May 2002 concerning the technical specification for interoperability relating to the rolling stock subsystem of the trans-European high-speed rail system referred to in Article 6(1) of Directive 96/48/EC. Accessed on: 2019-09-28

[5] Mlinaric, T[omislav] J[osip]; Rados, B[ozica] \& Vajdic, M[arko] (2017). Proposal for the Implementation of the European Rail Traffic Management System (ERTMS) to the Railway Network in the Republic of Croatia, Proceedings of the 28th DAAAM International Symposium, pp.0109-0117, B. Katalinic (Ed.), Published by DAAAM International, ISBN 978-3-902734-11-2, ISSN 1726-9679, Vienna, Austria DOI: 10.2507/28th.daaam.proceedings.014

[6] Martí-Henneberg, J. (2013). European integration and national models for railway networks. Journal of Transport Geography, Vol. 26, pp. 126-138. DOI: http://dx.doi.org/10.1016/j.trangeo.2012.09.004

[7] Rodrigue, J.P. \& Slack, B. (2017). Development of High Speed Train Traffic, 1964-2017. Available from: https://transportgeography.org/?page_id=1975 Accessed on: 2019-10-02

[8] Nigrin, T., Tomeš, Z., Seidenglanz, D., Mlsna, P. \& Dujka, J. (2017). The railway reform in Germany. Carolinum, ISBN 9788024636276, Prague.

Nigrin, T., Tomeš, Z., Seidenglanz, D., Mlsna, P. \& Dujka, J. (2017). Železniční reforma v Německu.

[9] Tomeš, Z., Růt, Š., Jandová, M., Seidenglanz, D. \& Rederer, V. (2017). The railway reform in Great Britain. Munipress, ISBN 978-80-210-8743-9, Brno.

Tomeš, Z., Růt, Š., Jandová, M., Seidenglanz, D. \& Rederer, V. (2017). Železniční reforma ve Velké Británii.

[10] Pellegrini, P. \& Rodriguez, J. (2013). Single European Sky and Single European Railway Area: A system level analysis of air and rail transportation. Transportation Research Part A, Vol. 57, pp. 64-86. DOI: http://dx.doi.org/10.1016/j.tra.2013.09.004

[11] Dobruszkes, F., Dehon, C. \& Givoni, M. (2014). Does European high-speed rail affect the current level of air services? An EU-wide analysis. Transportation Research Part A, Vol. 69, pp. 461-475.

[12] Albalate, D., Bel, G. \& Fageda, X. (2015). Competition and cooperation between high-speed rail and air transportation services in Europe. Journal of Transport Geography, Vol. 42, pp. 166-174.

[13] Koubek, Š. (2017). High-speed regional terminals - approaches, transport roles, situation in the Czech Republic. Bachelor thesis, Masaryk University, Brno.

Koubek, Š. (2017). Regionální terminály VRT - přístupy, dopravní role, české reálie. Bakalářská práce.

[14] Seidenglanz, D. (2007). Transport features of rural space. Disertation thesis, Masaryk University, Brno. Seidenglanz, D. (2007). Dopravní charakteristiky venkovského prostoru. Disertační práce.

[15] Dujka, J. (2014). The integrated public transport system in the Zlín region. Diploma thesis. Masaryk University, Brno.

Dujka, J. (2014). Integrovaný dopravní systém Zlínského kraje. Diplomová práce.

[16] Tranos, E. \& Mack, E. (2019). Big data: A new opportunity for transport geography? Journal of Transport Geography, Vol. 76, pp 232-234. DOI: https://doi.org/10.1016/j.trangeo.2018.08.003

[17] Seidenglanz, D. (2016). The big data usage in case study Velké Meziříčí. Available from: http://www.itregep.cz/media/100840/seidenglanz_tel_2016.pdf. ITREGEP. Accessed on: 2019-09-09 Seidenglanz, D. (2016). Využití big data v př́ípadové studii Velké Meziříčí.

[18] Kvizda, M., Tomeš, Z., Seidenglanz, D. \& Nigrin, T. (2017). Case study on the selected location of the VRT terminal. Faculty of Economics and Administration, Masaryk University, Brno. RIV: RIV/00216224:14560/17:00094423

Kvizda, M., Tomeš, Z., Seidenglanz, D. \& Nigrin, T. (2017). Případová studie na vybranou lokalitu terminálu VRT.

[19] https://www.bahn.com/cs/view/index.shtml (2019). Deutsche Bahn connection finder. Deutsche Bahn. Accessed on: 2019-10-10.

[20] http://www.idos.cz (2019). Connection finder primarily for Czech Republic and selected destinations in Europe, IDOS.cz. Accessed on: 2019-10-10.

[21] https://ondras.zarovi.cz/sql/demo/?keyword=default Online schema-of-SQL-database builder, Ondras.Zarovi.cz. Accessed on: 2019-10-10. 